\title{
TAFSIR TEMATIK TENTANG MOTIVASI DALAM PENDIDIKAN
}

\author{
Tri Sukitman \\ Dosen Pendidikan Guru Sekolah Dasar \\ STKIP PGRI Sumenep \\ tri.sukitman@stkippgrisumenep.ac.id
}

\begin{abstract}
Abstrack
Motivation is one of the important terminologies in Education, more specifically in Educational Psychology. In the learning process, motivation is even the first stage or phase of a number of stages that lead to the feedback phase. Motivation is one of the factors that influence the effectiveness of student learning activities. A motivation that encourages students to conduct learning activities. This encouragement will have a positive impact on the process of forming student learning achievements. Like Islam, which always encourages people to learn. The main function of motivation is as a booster in fulfilling a variety of human needs, which includes physical, psychological, even spiritual-transcendental needs. The other functions that correlate with each other are to move, direct, maintain, sustain, and select human behavior. Based on these functions, Baharuddin was able to conclude that the motivation is the main key in interpreting and giving birth to human actions, which in the Islamic concept is called niyyah and ibadah. Niyyah is the main booster of mankind to make or do charity, while ibadah is the goal of humans do or doing charity. So according to him human actions, are in the circle of niyyah and ibadah
\end{abstract}

Keywords: Thematic Interpretation, Motivation, Education

\begin{abstract}
Abstrak
Motivasi merupakan salah satu terminologi yang penting dalam IImu Pendidikan, dan lebih khusus lagi dalam Psikologi Pendidikan. Dalam proses pembelajaran, motivasi bahkan merupakan tahapan atau fase pertama dari sejumlah tahapan yang berujung pada fase umpan balik. Motivasi merupakan salah satu faktor yang mempengaruhi keefektifan kegiatan belajar siswa. Motivasilah yang mendorong siswa ingin melakukan kegiatan belajar. Dorongan ini akan memberikan dampak yang positif dalam proses pembentukan prestasi belajar siswa. Seperti agama Islam dimana selalu menganjurkan umatnya untuk belajar. Fungsi utama motivasi adalah sebagai pendorong dalam memenuhi berbagai ragam kebutuhan manusia, yang mencakup kebutuhan fisik, psikis, bahkan spiritual-transendental. Fungsi lainnya yang saling berkorelasi satu sama lain ialah menggerakkan, mengarahkan, menjaga, menopang, dan menyeleksi tingkah laku manusia. Berdasar fungsi-fungsi tersebut, Baharuddin sampai kepada kesimpulan bahwa motivasi menjadi kunci utama dalam menafsirkan dan melahirkan perbuatan manusia, yang dalam konsep Islam disebut niyyah dan 'ibadah. Niyyah merupakan pendorong utama manusia untuk berbuat atau beramal, sedangkan 'ibadah merupakan tujuan manusia berbuat atau beramal. Maka perbuatan manusia menurutnya, berada pada lingkaran niyyah dan 'ibadah.
\end{abstract}

Kata Kunci: Tafsir Tematik, Motivasi, Pendidikan 
ISSN 2548-9119

\section{PENDAHULUAN}

Motivasi merupakan salah satu terminologi yang penting dalam IImu Pendidikan, dan lebih khusus lagi dalam Psikologi Pendidikan. Dalam proses pembelajaran, motivasi bahkan merupakan tahapan atau fase pertama dari sejumlah tahapan yang berujung pada fase umpan balik (Baharuddin, 2007: 17). Menurut Catherine Soanes, Motivasi berasal dari kata Latin motivus. Dalam bahasa Inggris disebut motivation, yang merupakan bentukan dari kata dasar motive (Indonesia: motif). Maknanya adalah dorongan, alasan atau keinginan untuk melaksanakan sesuatu. Dalam psikologi, motivasi dimaknai sebagai terma yang merujuk kepada dorongan yang timbul atau dilakukan sebagai upaya pemenuhan kebutuhan diri dan tujuan tingkah laku.

Pendidikan merupakan aspek yang paling penting dalam melaksanakan transfer of knowledge. Salah satunya adalah dimana pendidikan merupakan proses pengembangan motivasi untuk belajar. Dimana motivasi merupakan syarat mutlak untuk belajar mengingat banyak siswa atau peserta didik yang mempunyai sifat malas, kurang senang, suka membolos, dan sebagainya.

Guru sebagai salah satu objek pembelajaran harus mampu dan dituntut untuk berperan aktif dalam pembentukan motivasi siswanya agar tetap mampu menyerap apa yang telah dilakukan dalam proses belajar mengajar berlangsung. Banyak anak tidak berkembang karena tidak diperolehnya motivasi yang tepat. Jika seseorang mendapat motivasi yang tepat, maka lepaslah tenaga yang luar biasa, sehingga tercapai hasil-hasil yang semula tidak terduga (Ngalim Purwanto, 2004: 6061).

Dengan demikian motivasi merupakan salah satu faktor yang mempengaruhi keefektifan kegiatan belajar siswa. Motivasilah yang mendorong siswa ingin melakukan kegiatan belajar. Dorongan ini akan memberikan dampak yang positif dalam proses pembentukan prestasi belajar siswa. Seperti agama Islam dimana selalu menganjurkan umatnya untuk belajar. Makalah ini akan membahas bagaimana konsep motivasi dalam al-Qur'an sebagai aspirasi dan inspirasi dalam mengembangkan pendidikan.

\section{PEMBAHASAN}

\section{A. Pembagian Motivasi}

Menurut Sardiman (2000: 71), secara lebih komprehensif kita dapat menyebut motif sebagai daya penggerak yang mendorong seseorang melakukan aktivitas tertentu untuk mencapai suatu tujuan. Dari motif timbul motivasi, yaitu daya penggerak yang telah menjadi aktif, terutama bila kebutuhan untuk mencapai sesuatu tujuan yang dikehendaki sudah dinilai mendesak atau penting oleh individu. Terdapat tiga elemen penting dalam motivasi:

a. Motivasi mengawali terjadinya perubahan energi dalam system neurofisiologi yang ada pada manusia. Perubahan energi itu menampakkan diri dalam berbagai bentuk kegiatan yang bersifat fisik.

b. Motivasi ditandai dengan munculnya rasa atau afeksi, yang relevan dengan persoalan-persoalan kejiwaan yang menentukan bentuk tingkah laku fisik yang diperbuat.

c. Motivasi dirangsang karena adanya tujuan, sehingga sebenarnya lebih sebagai respon dari suatu aksi, yaitu tujuan. Motivasi memang ada yang muncul dari dalam diri atau batin manusia, tetapi kemunculannya terdorong oleh adanya unsur lain dari luar.

Selanjutnya Sardiman menjelaskan bahwa motivasi memiliki beberapa pembagian. Jika dilihat dari dasar pembentukannya, dikenal adanya motivasi bawaan, yaitu motivasi yang dimiliki manusia yang merupakan bawaan sejak lahir. Contohnya dorongan untuk makan dan minum serta dorongan seksual. Karenanya lazim pula 
disebut motivasi fisiologik. Motivasi kedua ialah motivasi yang dipelajari, atau disebut juga motivasi afiliatif atau motivasi objektif, yang terbentuk sebagai prasyarat manusia sebagai makhluk sosial, dimana manusia memerlukan kelengkapan atau kecakapan tertentu dalam berhubungan dengan manusia lain atau dengan hal-hal yang berada di luar diri individu.

Pembagian

lainnya mengklasifikasikan motivasi menjadi motivasi jasmaniah dan motivasi rohaniah. Motivasi jasmaniah ini kurang lebih semakna dengan motivasi bawaan. Termasuk di dalamnnya refleks, insting dan nafsu. Motivasi rohaniah kurang lebih sama dengan motivasi afiliatif, dan kemauan (melakukan sesuatu). Sedangkan, menurut Baharuddin, bentuk pembagian lainnya menggolongkan motivasi kedalam motivasi intrinsik dan motivasi ekstrinsik. Motivasi pertama muncul dari dalam diri atau dari batin manusia, yang muncul sebagai akibat adanya tiga faktor; kebutuhan, pengetahuan, dan aspirasi atau cita-cita. Motivasi yang kedua datang dari luar diri individu sebagai akibat adanya faktor-faktor persaingan atau kompetisi, serta faktor imbalan yang bisa berupa hadiah atau ganjaran yang baik atau bisa juga berupa hukuman atau sanksi.

\section{B. Fungsi Motivasi}

Fungsi utama motivasi adalah sebagai pendorong dalam memenuhi berbagai ragam kebutuhan manusia, yang mencakup kebutuhan fisik, psikis, bahkan spiritual-transendental. Fungsi lainnya yang saling berkorelasi satu sama lain ialah menggerakkan, mengarahkan, menjaga, menopang, dan menyeleksi tingkah laku manusia. Berdasar fungsi-fungsi tersebut, Baharuddin sampai kepada kesimpulan bahwa motivasi menjadi kunci utama dalam menafsirkan dan melahirkan perbuatan manusia, yang dalam konsep Islam disebut niyyah dan 'ibadah.
Niyyah merupakan pendorong utama manusia untuk berbuat atau beramal, sedangkan ibadah merupakan tujuan manusia berbuat atau beramal. Maka perbuatan manusia menurutnya, berada pada lingkaran niyyah dan 'ibadah (Baharuddin, 2007: 239). Apakah niyyah yang mendorong perbuatan manusia dalam Islam, lebih khusus lagi dalam AlQur'an, untuk berbuat 'ibadah? Tidak lain ridla Allah. Ridla-lah sinonim motivasi dalam Al-Qur'an.

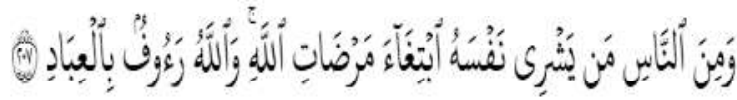

Artinya: Dan di antara manusia ada orang yang mengorbankan dirinya karena mencari keridhaan Allah; dan Allah Maha Penyantun kepada hamba-hamba-Nya. (QS. al-Baqarah: 207).

Dalam Tafsir Ibn Katsir dijelaskan: Ibn 'Abbas, Anas, Sa'id bin Musayyib, Abu 'Uthman An-Nahdi, 'Ikrimah dan beberapa sahabat lain menceritakan bahwa ayat ini berkaitan dengan Suhayb bin Sinan Ar-Rumi. Ketika Suhayb masuk Islam di Makkah dan menyatakan ikut hijrah ke Madinah, orang-orang Quraisy mengancamnya dengan mengatakan dia baru boleh pergi jika menyerahkan seluruh harya kekayaannya. Ternyata ia memberikan hartanya. Umar bin Khattab dan sejumlah sahabat menemuinya di pinggiran kota Madinah bernama AlHarrah dan mengatakan padanya, pertukaran paksa yang dialaminya berbuah sukses. Mengapa? Umar mengatakan Allah telah menurunkan ayat di atas karena apa yang dialaminya. Ayat ini juga mencakup setiap mereka yang berjihad dengan harta di jalan Allah (Lihat Tafsir Ibn Kathir edisi Inggris dalam http:// salafidb.googlepages.com/ salafidb.4.0.exe).

Mengaitkan dorongan dengan kebutuhan dalam motivasi dikemukakan dalam struktur piramida hirarki 
kebutuhan manusia oleh Abraham Maslow:

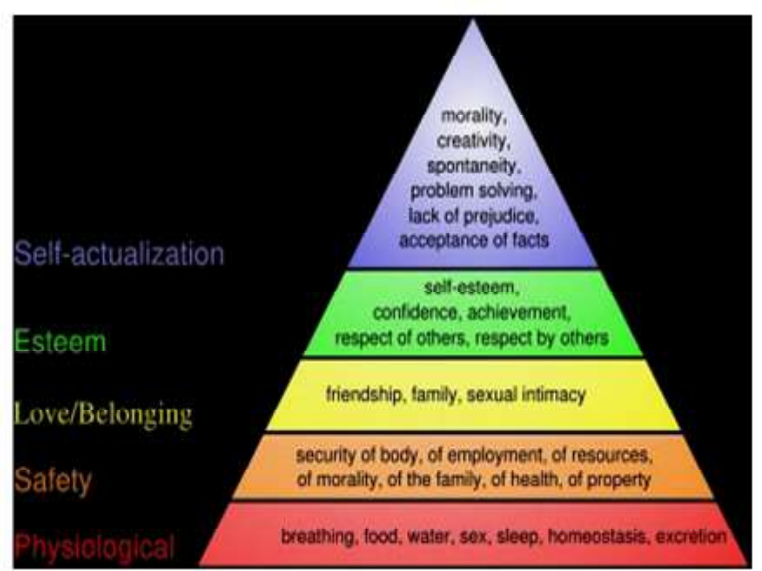

Dalam piramida tersebut, Maslow memaparkan bahwa kebutuhan paling mendasar manusia adalah kebutuhan fisiologis seperti bernafas, makan, minum, seks, tidur, pemeliharaan stabilitas keseimbangan fisik (homeostasis), dan buang air; yang apabila salah satu di antaranya saja tidak terpenuhi maka akan menghasilkan ketidakseimbangan dalam berfikir dan bertingkahlaku, bahkan dapat menimbulkan ketidaknyamanan dan rasa sakit.

Kebutuhan pada tahapan kedua adalah kebutuhan akan keamanan hidup yang mencakup keamanan fisik, pekerjaan, sumber daya (yang dimiliki), moralitas, keluarga, kesehatan, dan kekayaan.Pada tahapan berikutnya muncul kebutuhan akan rasa cinta kasih dan rasa memiliki apakah itu yang meliputi kelompok sosial yang kecil seperti persahabatan, keluarga, dan hubungan seks dengan pasangan, ataupun dari kelompok yang lebih besar seperti organisasi profesional dan atau kemasyarakatan, bahkan agama. Tahapan keempat merupakan kebutuhan akan penghargaan yang termanifestasikan dalam perasaan kemampuan atau prestasinya dihargai, rasa percaya diri, sikap penghormatan dari dan kepada pihak lain.

Kemudian pada tahapan puncak, manusia memiliki keinginan dalam pemenuhan kebutuhan akan aktualisasi diri dalam bentuk merealisir semua kemampuan dan potensi diri yang dimiliki untuk melakukan proses kreatif dalam meraih prestasi yang lebih baik dalam hidupnya. Ini mencakup pencapaian dalam aspek-aspek moralitas, kreatifitas, spontanitas, pemecahan masalah, objektifitas, dan penerimaan fakta (realita). Termasuk dalam tahapan ini upaya pencapaian dalam bidang pendidikan.

Dalam kajian Psikologi Islam dari Baharuddin, manusia memiliki enam susunan dimensi jiwa yang urutannya dari yang tertinggi ke yang terendah berturut-turut; al-fitrah, al-ruh, al-qalb, al'aql, al-nafsu, dan al-jism. Jika dibandingkan dengan hirarki piramida Maslow, maka kebutuhan-kebutuhan dasar dari dimensi-dimensi tersebut akan meliputi kebutuhan jismiah (sama dengan kebutuhan fisiologis dari Maslow), kebutuhan afsiah yang mencakup kebutuhan akan rasa aman dan kebutuhan seksual pada dimensi jiwa al-nafsu, kebutuhan penghargaan diri pada dimensi al-aql, dan kebutuhan cinta dan kasih sayang pada dimensi al-qalb. (Gabungan dari kebutuhan kedua, ketiga, dan keempat dalam piramida Maslow).

Dari kebutuhan-kebutuhan tersebut, demikian Baharuddin, ada tiga jenis motivasi, yaitu motivasi jismiah, motivasi nafsiah dan motivasi ruhaniah. Motivasi jismiah adalah motivasi yang timbul untuk memenuhi kebutuhankebutuhan fisik-biologis.

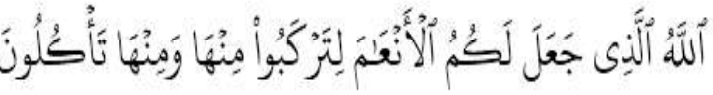

Artinya: Allahlah yang menjadikan binatang ternak untuk kamu, sebagiannya untuk kamu kendarai dan sebagiannya untuk kamu makan. (QS. al-Mu'min: 79).

Motivasi nafsiah adalah motivasi untuk pemenuhan kebutuhan-kebutuhan yang bersifat psikologis, seperti rasa aman, keintiman seksual, penghargaan 
diri, rasa ingin tahu, rasa memiliki, dan rasa cinta. Motivasi nafsiah ini sekarang dikenal dengan istilah hak asasi manusia. Beberapa ayat yang menunjukkan bagaimana motivasi jenis ini didorong dan diakui dalam Islam, antara lain yang menyangkut rasa aman dan hak untuk menetap di tempat kediamannya tanpa gangguan dari pihak lain:

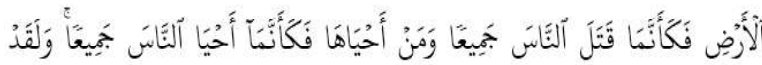

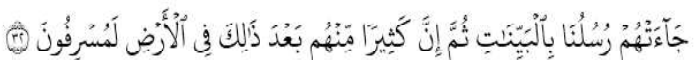

Artinya: Oleh karena itu Kami tetapkan (suatu hukum) bagi Bani Israil, bahwa: Barangsiapa yang membunuh seorang manusia, bukan karena orang itu (membunuh) orang lain, atau bukan karena membuat kerusakan dimuka bumi, Maka seakan-akan Dia telah membunuh manusia seluruhnya. dan Barangsiapa yang memelihara kehidupan seorang manusia, Maka seolah-olah Dia telah memelihara kehidupan manusia semuanya. dan Sesungguhnya telah datang kepada mereka Rasul-rasul Kami dengan (membawa) keterangan-keterangan yang jelas, kemudian banyak diantara mereka sesudah itu sungguh-sungguh melampaui batas dalam berbuat kerusakan dimuka bumi. (QS. alMaidah: 32).

Motivasi ruhaniah adalah motivasi untuk memenuhi kebutuhan yang bersifat spiritual, seperti aktualisasi diri dan agama, seperti yang dijelaskan dalam al-Qur'an berikut:

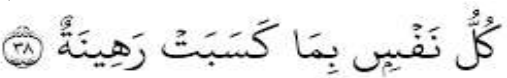

Artinya: Tiap-tiap diri bertanggung jawab atas apa yang telah diperbuatnya, (QS. al-Mudatsir: 38).

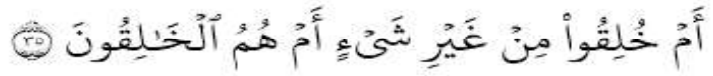

Artinya: Apakah mereka diciptakan tanpa sesuatupun ataukah mereka yang menciptakan (diri mereka sendiri)? (QS. at-Thur: 35)
Artinya: Katakanlah: "Jikalau ada tuhan-tuhan di samping-Nya, sebagaimana yang mereka katakan, niscaya tuhan-tuhan itu mencari jalan kepada Tuhan yang mempunyai 'Arsy". (QS. al-Israa': 42).

Maksud dari motivasi ini adalah manusia untuk memuaskan kebutuhannya akan adanya Tuhan; atau kebutuhan dalam mempertuhankan "Tuhan", kebutuhan untuk menyembah sesuatu yang dipertuhankan, yang dalam penyebutan M. Quraish Shihab disebut "insting keberagamaan". Dalam bahasa yang lebih umum, Maslow menyebut ini sebagai meta-motivasi, yaitu kebutuhan mewujudkan potensi luhur batin manusia. Aplikasinya dalam Psikologi Islam adalah 'ibadah, yang dalam perumusan Hasan Langgulung (Hasan Langgulung, 1986: 320), disebut sebagai pengembangan sifat-sifat Allah yang terangkum dalam al-asma alhusna yang dititipkan kepada manusia. Sifat-sifat tersebut masih dalam bentuk potensi sehingga perlu dikembangkan. Sebagai contoh Allah memerintahkan shalat agar potensi al-qudds (suci) berkembang. Allah juga memerintahkan belajar agar potensi al-'alim (mengetahui) berkembang, demikian seterusnya Aplikasi Motivasi Dalam Pendidikan.

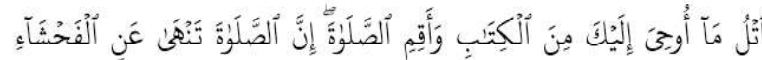

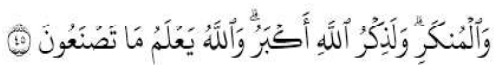

Artinya: Bacalah apa yang telah diwahyukan kepadamu, Yaitu Al kitab (Al Quran) dan dirikanlah shalat. Sesungguhnya shalat itu mencegah dari (perbuatan- perbuatan) keji dan mungkar. dan Sesungguhnya mengingat Allah (shalat) adalah lebih besar (keutamaannya dari ibadatibadat yang lain). dan Allah mengetahui apa yang kamu kerjakan. (QS. al-Ankabut: 45).

Makna ayat 45 dari Surah Al-Ankabut di atas secara jelas mengungkapkan 
ISSN 2548-9119

dua hal. Pertama, motivasi manusia didorong untuk membaca Al-Qur'an dengan tujuan untuk "merenungkan serta mempelajari rahasia dan manfaat yang terkandung di dalamnya" (Al-Maraghi, 1993: 252). Motivasi dirangsang karena tujuan tersebut. Motivasi ini muncul dari dalam diri atau batin manusia, tetapi kemunculannya terdorong oleh adanya unsur lain dari luar, dalam hal ini isi AlQur'an.

Kedua, bahwa potensi kesucian manusia akan terjaga dari dosa apabila mengerjakan shalat dengan khusyu' dan ikhlas dan dengan semata mengharapkan keridlaan Allah SWT. Karena sebagaimana diungkapkan AlMaraghi, dalam shalat terdapat berbagai macam ibadat seperti bertakbir, bertasbih, membaca ayat-ayat Al-Qur'an, bahkan bersujud di hadapanNya. Dengan seluruh rangkaian ibadat yang terkandung dalam shalat tersebut, maka manusia akan senantiasa berada dalam keadaan suci.

A. Aplikasi Motivasi Dalam Pendidikan

Secara umum, pendidikan bertujuan mengembangkan tiga fungsi dasar dalam diri manusia, yaitu fungsi kognitif, afektif, dan psikomotorik. Fungsi kognitif mencakup kemampuan mengetahui, menganalisa, mensintesa, menerapkan, dan mengevaluasi. Fungsi afektif meliputi kemampuan menerima, menanggapi, menghargai, membentuk, dan berkepribadian. Fungsi psikomotorik berkaitan dengan kegiatan fisik, penguasaan tubuh dan gerak, seperti berjalan, berlari, dan melompat.

\section{Fungsi Kognitif}

Dalam aplikasi yang lebih luas, fungsi kognitif meliputi wilayah kesadaran, pemikiran, pengetahuan, penafsiran, pemahaman, gagasan dan kecerdasan. Jika dihubungkan dengan enam dimensi psikis manusia yang meliputi al-jism, alnafsu, al-'aql, al-qalb, al-ruh, dan alfitrah, ditemukan tiga struktur fungsi kognitif, yaitu fungsi kognitif ruhaniah, kognitif nafsiah, dan kognitif jismiah (Abu Ahmadi, 2001: 223-224).

Fungsi kognitif ruhaniah ada yang bersumber dari dimensi alfitrah, seperti pengenalan, kesadaran dan pengetahuan yang bersifat transendental dan eskatologis, yaitu pengetahuan atau kesadaran tentang keagamaan dan keimanan.

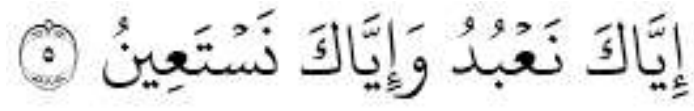

Artinya: Hanya Engkaulah yang Kami sembah, dan hanya kepada Engkaulah Kami meminta pertolongan. (QS. al-Fatihah: 5)

Na'budu diambil dari kata 'ibaadat: kepatuhan dan ketundukan yang ditimbulkan oleh perasaan terhadap kebesaran Allah, sebagai Tuhan yang disembah, karena berkeyakinan bahwa Allah mempunyai kekuasaan yang mutlak terhadapnya. Nasta'iin (minta pertolongan), terambil dari kata isti'aanah: mengharapkan bantuan untuk dapat menyelesaikan suatu pekerjaan yang tidak sanggup dikerjakan dengan tenaga sendiri.

Ada pula fungsi kognitif ruhaniah yang bersumber dari dimensi al-ruh yang menghasilkan pengenalan, pengetahuan, dan kesadaran spiritual yang tidak dapat dikonsepsikan, yang menjelma dalam bentuk kebijaksanaan dan sifat-sifat manusiawi.

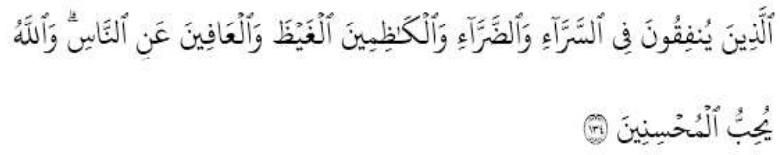

Artinya: (yaitu) orang-orang yang menafkahkan (hartanya), baik di waktu lapang maupun sempit, dan orang-orang yang menahan amarahnya dan mema'afkan (kesalahan) orang. Allah menyukai 
orang-orang yang berbuat kebajikan. (QS. al-Imran: 134).

Hanya manusia yang telah memiliki kesadaran spiritual yang secara sadar mampu memotivasi dirinya untuk melaksanakan sifatsifat kebajikan manusia seperti yang dicontohkan dalam ayat 134 dari Surah Ali Imran di atas.

Dalam penjelasannya terhadap ayat tersebut, Ibn Kathir mengisahkan tentang salah satu hadis Imam Ahmad dari Abu Hurairah, yang juga tercantum dalam Shahihain yang menyatakan bahwa Rasulullah saw bersabda:

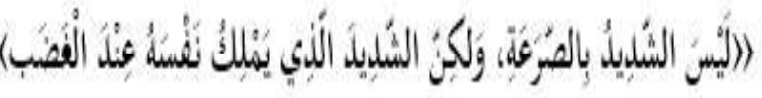

Manusia yang kuat bukanlah manusia yang mampu menaklukkan orang lain secara fisik. Manusia yang kuat adalah manusia yang mampu mengendalikan amarahnya.(AlHadist).

Fungsi kognitif nafsiah juga mencakup kognitif qalbiah yang antara lain mencakup penghayatan, pemahaman, dan pencarian makna yang menjelma dalam bentuk pengenalan benar-salah, baik-buruk, tindakan yang harus dilakukan vis a vis tindakan yang harus dihindari, yang pada gilirannya mengantarkan manusia kepada kemampuan bersikap dan mengelola kesabaran. Fungsi kognitif qalbiah ini sekarang dikenal dengan terma kecerdasan emosional. Ini sejalan dengan ayat dan hadis di atas dan tercermin dalam banyak ayat, seperti:

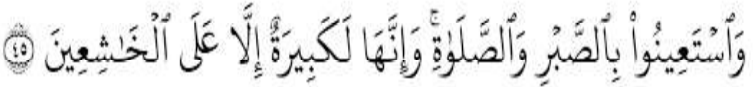

Artinya: Jadikanlah sabar dan shalat sebagai penolongmu. dan Sesungguhnya yang demikian itu sungguh berat, kecuali bagi orang-orang yang khusyu', (QS. al-Baqarah:

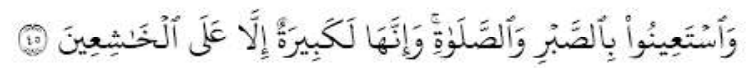

Artinya: Dan sungguh akan Kami berikan cobaan kepadamu, dengan sedikit ketakutan, kelaparan, kekurangan harta, jiwa dan buahbuahan. dan berikanlah berita gembira kepada orang-orang yang

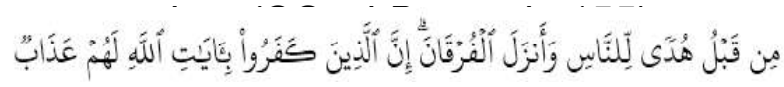

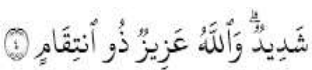

Artinya: Sebelum (Al Quran), menjadi petunjuk bagi manusia, dan Dia menurunkan Al Furqaan. Sesungguhnya orang-orang yang kafir terhadap ayat-ayat Allah akan memperoleh siksa yang berat; dan Allah Maha Perkasa lagi mempunyai Balasan (siksa). (QS. al-Imran: 4)

Fungsi kognitif nafsiah pun mencakup kognitif 'aqliah, yaitu kemampuan memperoleh pengetahuan melalui daya-daya akal, darimana manusia bisa mengolah informasi untuk memperoleh ilmu pengetahuan. Kemampuan tersebut meliputi berfikir (tafakkur), mencari makna di balik teks atau realitas (tadabbur), merenung (ta'ammul), memperhatikan dengan cermat (istibsar), observasi atau eksperimen (nazar). Sehingga menghasilkan:

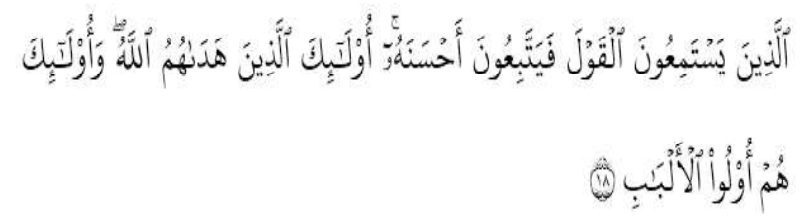

Artinya: Yang mendengarkan Perkataan lalu mengikuti apa yang paling baik di antaranya. mereka Itulah orang-orang yang telah diberi Allah petunjuk dan mereka Itulah orang-orang yang mempunyai akal. (QS. az-Zumar: 18) 45) 
Fungsi inilah yang paling terkait dengan masalah pendidikan. Ayatayat Al-Qur'an penuh dengan kandungan menyangkut fungsi kognitif nafsiah ini. Salah satu di antaranya :
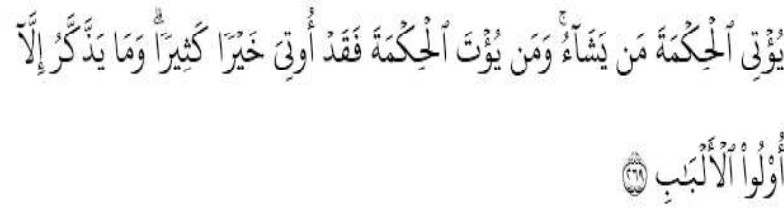

Artinya: Allah menganugerahkan Al Hikmah (kefahaman yang dalam tentang Al Quran dan As Sunnah) kepada siapa yang dikehendakiNya. dan Barangsiapa yang dianugerahi hikmah, ia benarbenar telah dianugerahi karunia yang banyak. dan hanya orangorang yang berakallah yang dapat mengambil pelajaran (dari firman Allah). (QS. al-Baqarah: 269)

Dalam Tafsir Ibn Kathir diungkapkan bahwa 'Ali bin Abi Talhah meriwayatkan, Ibn 'Abbas mengatakan bahwa yang dimaksud dengan al-hikmah adalah pengetahuan (dalam) Al-Qur'an, seperti apa yang jelas dan terang dan apa yang tidak, apa yang dibolehkan dan apa yang tidak, dan yang sejenisnya. Imam Ahmad meriwayatkan dari Ibnu Mas'ud, bahwa Rasulullah saw mengatakan:

"Tidak ada kecemburuan kecuali dalam (melihat) dua hal : orang yang Allah berikan kekayaan dan ia membelanjakannya dengan benar dan orang yang memperoleh al-hikmah dan ia mengamalkannya dan mengajarkannya kepada yang lain" (Dalam Shahih Bukhari, dikemukakan bahwa al-hikmah adalah kebenaran di luar nubuwwah).

Surah pertama yang turun dari AlQur'an adalah surah Al-'Alaq. Ia berisi sejumlah katakata yang sangat terkait dengan pendidikan dan ilmu pengetahuan. Dan yang perlu dipahamkan dalam hal ini, surah tersebut tidak berisi kisah atau renungan, tetapi perintah yang tegas : Iqra' (Bacalah!). Kata-kata yang dimaksud selain dari 'iqra' seperti 'allama (mengajar), al-qalam (pena; tulis baca), ya'lam (mengetahui).

Muhammad Quraish Shihab mengemukakan, ada perbedaan yang penting antara perintah iqra' dalam ayat pertama dengan ayat ketiga dari surah tersebut, dimana ayat pertama berisi syarat yang harus dipenuhi seseorang ketika membaca, yaitu harus membaca dengan nama Allah (Bismillah), sama halnya dengan ketika kita membaca niat untuk melaksanakan sesuatu yang baik, dan pada ayat ketiga adalah manfaat yang diperoleh setelah membaca, yaitu Kemahapemurahan atau Kemahamuliaan Tuhan. Karenanya ayat-ayat ini dia tafsirkan sebagai : Bacalah, Tuhanmu akan menganugerahkan pada kita karam (al-akram) yaitu kemurahanNya dengan memberi kepada kita pengetahuan tentang apa yang kita tidak ketahui. Lalu dengan pengetahuan itu kita memperoleh manfaat yang berguna (Quraish Shihab, 1994: 170).

Hal lain yang tidak kalah menariknya ialah bagaimana Allah SWT melalui Al-Qur'an berulangulang memotivasi manusia agar mencari ilmu.

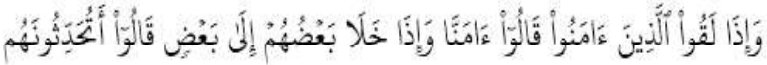

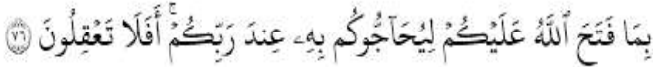
Artinya: Dan apabila mereka berjumpa dengan orang-orang yang beriman, mereka berkata:" Kamipun telah beriman," tetapi apabila mereka berada sesama mereka saja, lalu mereka berkata: "Apakah kamu menceritakan kepada mereka (orang-orang mukmin) apa yang telah diterangkan Allah 
Tri Sukitman

kepadamu, supaya dengan demikian mereka dapat mengalahkan hujjahmu di hadapan Tuhanmu; tidakkah kamu mengerti?" (QS. al-Baqarah: 76)

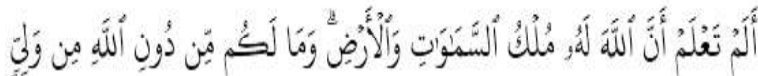

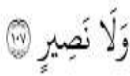

Artinya: Tiadakah kamu mengetahui bahwa kerajaan langit dan bumi adalah kepunyaan Allah? dan tiada bagimu selain Allah seorang pelindung maupun seorang penolong. (QS. alBaqarah: 107)

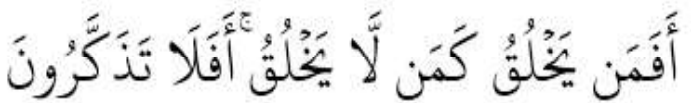

Artinya: Maka Apakah (Allah) yang menciptakan itu sama dengan yang tidak dapat menciptakan (apaapa) ?. Maka mengapa kamu tidak mengambil pelajaran. (QS. anNahl: 17)

Hal lain yang dapat membuktikan bagaimana Allah SWT memotivasi manusia melalui Al-Qur'an terlihat dari metode kisahkisah yang termuat. Apakah kisahkisah tersebut simbolik atau benarbenar terjadi, tetapi ia memancing rasa ingin tahu kita tentang berbagai cabang ilmu pengetahuan, seperti pengetahuan alam yang antara lain termuat dalam bagianbagian awal dari Surah An-Nahl dan ayat-ayat kauniyah lainnya, atau tentang sejarah; kisah Fir'aun, Karun, dan sejarah Rasul-rasul.

Bagian terakhir dari fungsi kognitif nafsiah ialah kognitif naluriah, yaitu yang berkaitan dengan panca indra (al-jism). Bagian ini pun dipaparkan dalam AlQur'an dengan tujuan memotivasi manusia agar memanfaatkannya untuk kebaikan, karena:

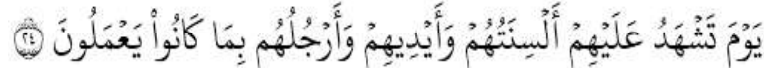

Artinya: Pada hari (ketika), lidah, tangan dan kaki mereka menjadi saksi atas mereka terhadap apa yang dahulu mereka kerjakan. (QS. an-Nur: 24)

Seperti juga yang diulang kembali oleh Allah SWT:

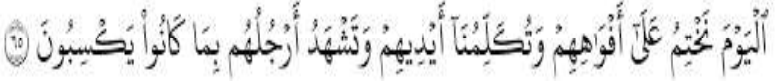

Artinya: Pada hari ini Kami tutup mulut mereka; dan berkatalah kepada Kami tangan mereka dan memberi kesaksianlah kaki mereka terhadap apa yang dahulu mereka usahakan. (QS. Yaasin: 65)

\section{Fungsi Afektif}

Fungsi afektif merupakan akumulasi dari pengalaman emosional yang berfungsi melakukan pertimbangan dan penilaian dalam menentukan sikap terhadap sesuatu. Fungsi ini terbagi tiga, yaitu afektif ruhaniah, afektif nafsiah dan afektif jismiah. Fungsi afektif ruhaniah berfungsi menentukan sikap berdasar pertimbangan keyakinan spiritual dan keyakinan agama. Dalam Islam, pertimbangan didasarkan kepada prinsip dan aturan yang ditetapkan agama yang termanifestasi dalam sikap ihsan, yaitu manusia berbuat dan bertingkah laku baik karena menyadari selalu diawasi Allah SWT. Sikap insan pada hakikatnya adalah kemampuan melibatkan dan merasakan kehadiran Allah dalam kehidupan manusia, sebagaimana jika kita menyadari ayat berikut:
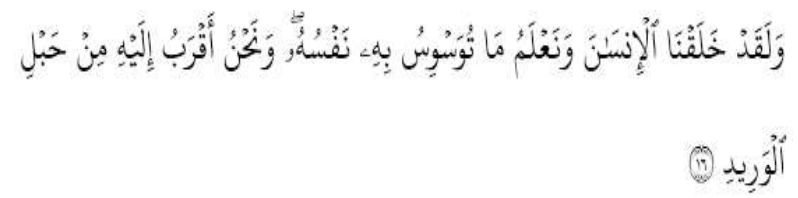
Artinya: Dan Sesungguhnya Kami telah menciptakan manusia dan mengetahui apa yang dibisikkan oleh hatinya, dan Kami lebih dekat kepadanya daripada urat lehernya, (QS. Qaaf: 16)

Atau sebagaimana yang dipraktekkan Rasul Ibrahim a.s.:

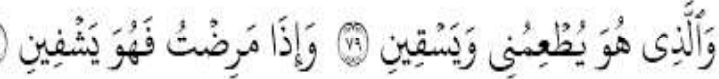
Artinya: Dan Tuhanku, yang Dia memberi Makan dan minum kepadaKu, Dan apabila aku sakit, Dialah yang menyembuhkan Aku, (QS. asySyu'raa': 79-80)

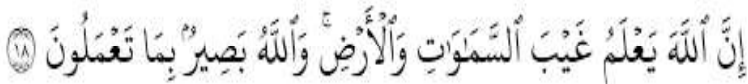

Artinya: Sesungguhnya Allah mengetahui apa yang ghaib di langit dan bumi. dan Allah Maha melihat apa yang kamu kerjakan. (QS. al-Hujarat: 18)

Terdapat puluhan ayat dalam AlQur'an yang terkait dengan sifatNya dalam Al-Asma al-Husna yang senada dengan ayat di atas, seperti Al-Bashr (Maha Melihat), Al-Raqib (Maha Pengawas), Al-Syahid (Maha Menyaksikan), Al-Sami' (Maha Mendengar).

Fungsi afektif nafsiah terbagi kepada afektif 'aqliah, afektif qalbiah dan afektif naluriah yang ketiganya secara prinsip kurang lebih sama. Fungsi afektif nafsiah 'aqliah adalah penentuan sikap berdasar pertimbangan yang logis dan rasional. Fungsi afektif nafsiah qalbiah adalah penentuan sikap berdasar pertimbangan baik dan buruk. Sedang fungsi afektif nafsiah naluriah adalah penentuan sikap berdasar untung rugi yang didasarkan kepada pertimbangan logik, etik, dan manfaat. Salah satu dari sekian banyak ayat menyangkut hal ini tertuang dalam ayat 58 Surah Al-Mu'min:

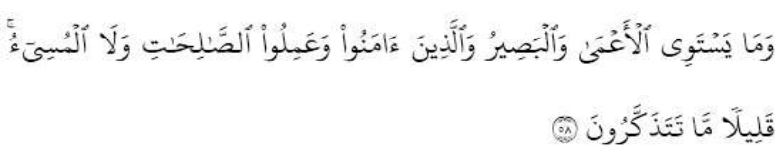

Artinya: Dan tidaklah sama orang yang buta dengan orang yang melihat, dan tidaklah (pula sama) orang-orang yang beriman serta mengerjakan amal saleh dengan orang-orang yang durhaka. sedikit sekali kamu mengambil pelajaran. (QS. al-Mu'min: 58)

Fungsi afektif jismiah adalah penentuan sikap berdasar kepentingan kebutuhan fisikbiologis. Dalam hal ini Islam mengajarkan kepada kita untuk berhati-hati dalam menggunakan panca indra, yang selayaknya hanya dimanfaatkan kepada hal-hal yang diridlai Allah SWT.

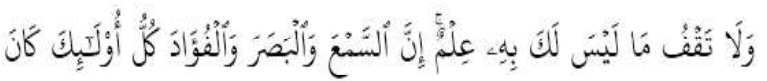

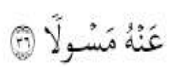

Artinya: Dan janganlah kamu mengikuti apa yang kamu tidak mempunyai pengetahuan tentangnya. Sesungguhnya pendengaran, penglihatan dan hati, semuanya itu akan diminta pertanggungan jawabnya. (QS. alIsra': 36).

\section{Fungsi Psikomotorik}

Fungsi psikomotorik dalam telaah Prof Baharuddin dinamai fungsi amalan, sebab menurutnya fungsi psikomotorik cenderung kepada tingkah laku mekanistik yang dilaksanakan tanpa melalui proses penghayatan dan kesadaran, sedang fungsi amalan dapat mencakup tingkah laku humanistik. Fungsi amalan dalam perumusannya adalah bertemunya daya batin yang mengarahkan kehidupan manusia dengan daya lahir yang melingkupi dan mendukungnya dalam gerakan atau perbuatan. 
dikemukakan dalam Surah Luqman ayat 20:

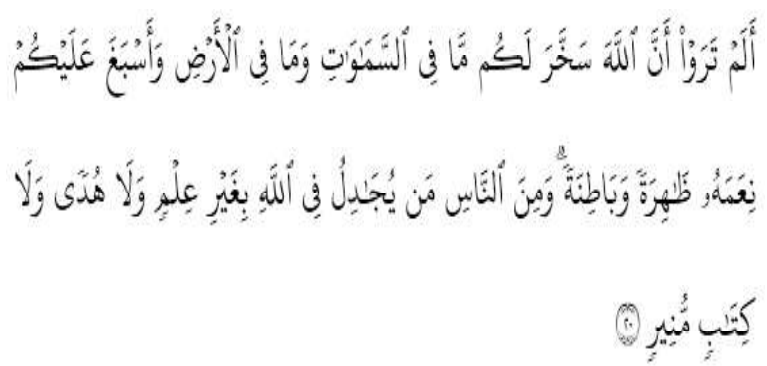

Artinya: Tidakkah kamu perhatikan Sesungguhnya Allah telah menundukkan untuk (kepentingan)mu apa yang di langit dan apa yang di bumi dan menyempurnakan untukmu nikmat-Nya lahir dan batin. dan di antara manusia ada yang membantah tentang (keesaan) Allah tanpa ilmu pengetahuan atau petunjuk dan tanpa kitab yang memberi penerangan. (QS. Luqman: 20).

\section{Kesimpulan}

Dalam dunia pendidikan mikro, bentuk motivasi yang lazim dilakukan para pendidik mencakup kegiatan seperti memberi angka yang merupakan simbol dari nilai kegiatan belajar. Angka yang baik dan tinggi biasanya memperkuat motivasi peserta didik dalam belajar. Bentuk lainnya adalah menghidupkan kompetisi yang sehat di antara para peserta didik. Bahkan dalam banyak bidang kehidupan manusia, semangat berkompetisi adalah ajang memperkuat prestasi. Demikian pula dengan memberikan pujian dan penghargaan atas keberhasilan seseorang, serta memberikan sanksi atau hukuman atas kurangnya motivasi (Sardiman, 2000: 89-92). Apakah hadiah dan hukuman yang tercantum dalam Al-Qur'an? Jawabnya : surga dan neraka.

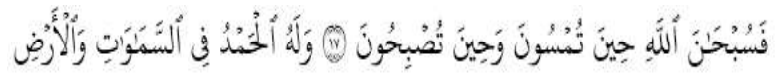

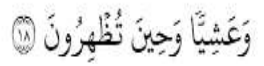

Artinya: Maka bertasbihlah kepada Allah di waktu kamu berada di petang hari dan waktu kamu berada di waktu subuh, Dan bagi-Nyalah segala puji di langit dan di bumi dan di waktu kamu berada pada petang hari dan di waktu kamu berada di waktu Zuhur. (QS. ar-Rum: 17-18)

Kualitas lainnya yang diperlukan ialah mereka yang taat asas dan teguh memegang prinsip serta senantiasa tetap konsisten. Dalam "bahasa" Islam, kekonsistenan dan ketaatan tersebut disebut istiqamah, sebagaimana antara lain dikemukakan dalam ayat berikut:

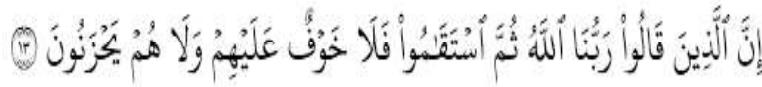

Artinya: Sesungguhnya orang-orang yang mengatakan: "Tuhan Kami ialah Allah", kemudian mereka tetap istiqamah. Maka tidak ada kekhawatiran terhadap mereka dan mereka tiada (pula) berduka cita. (QS. al-Ahqaaf: 13)

Inti dari keseluruhan pengembangan kualitas yang diperlukan dalam menanamkan dan menggerakkan motivasi adalah untuk menjadikan umat muslim benar-benar menjadi muslim (orang yang berserah diri). 


\section{Daftra Pustaka}

Abraham Maslow. 1943. "A Theory of Human Motivation", Psychological Review 50 . hlm. 370-396, dalam http://en.wikipedia.org/wiki/Maslow's_hierarchy_of_needs.

Ahmadi, Abu. 2001. Ilmu Pendidikan. Jakarta: Rineka Cipta.

Al-Maraghi, Ahmad Mustafa. 1993. Terjemah Tafsir Al-Maraghi, Juz 19,20,21, terj. Anwar Rashidi dan M. Shohib, et.al. Semarang: Toha Putra.

Baharuddin. 2007. Teori Belajar dan Pembelajaran, Yogyakarta: Ar-Ruzz Media.

Baharuddin. 2007. Paradigma Psikologi Islami. Yogyakarta: Pustaka Pelajar.

Catherine Soanes, Angus Stevenson, eds., Concise Oxford English Dictionary (Eleventh Edition), electronic edition, (London : Oxford University Press, tt.).

Langgulung, Hasan. 1986. Teori-teori Kesehatan Mental. Jakarta: Al-Husna.

Nashiruddin Al-Albani, Muhammad . Ringkasan Shahih Bukhari, edisi elektronik dari Gema Insani Press, (HaditsWeb) pada http ://salafidb.googlepages.com

Purwanto, Ngalim. 2004. Psikologi Pendidikan. Bandung: Rosda Karya.

Sardiman. 2000. Interaksi dan Motivasi Belajar Mengajar. Jakarta: Rajawali Pers.

Shihab, Quraish.1994. Membumikan Al-Qur'an. Bandung: Mizan. Qur'an, Jakarta: Lentera Hati.

2000. Menyingkap Tabir Ilahi, Asma al Husna dalam Perspektif Al- 